

\title{
Vanessa Beatriz Bortulucce REFLEXÕES SOBRE A FORMAÇÃO DA POÉTICA de Umberto Boccioni em "Beata solitudo - Sola beatitudo"
}

\begin{abstract}
No ano de 1908, Umberto Boccioni (1882-1916), artista do Futurismo italiano, produziu a segunda versão do desenho "Beata solitudo - Sola beatitudo", obra que expressa o contraste entre os valores antigos e modernos vivenciado pelo artista em seus primeiros anos em Milão. Este artigo procura analisar as principais influências estéticas que conduziram Boccioni na elaboração desse desenho, um dos mais representativos dentro de sua poética pré-futurista, e de que maneira essa obra antecipa os principais elementos de sua arte propriamente futurista.
\end{abstract}

palavras-chave: Umberto Boccioni; arte moderna; Futurismo; desenho

In the year of 1908, Umberto Boccioni (1882-1916), artist of the Italian Futurism, produced a second version of the drawing "Beata solitudo - Sola beatitudo", a work which expresses the contrast between the ancient and the modern values, experienced by the artist in his first years living in Milan. This article intends to study the main aesthetical influences which have guided Boccioni in this work, one of the most important ones in his pre-futurist aesthetics, as well as to demonstrate how this work anticipates the main elements of his futurist art.

keywords: Umberto Boccioni; modern art; Futurism; drawing

Em 1908, um ano antes do lançamento do Manifesto do Futurismo nas páginas do jornal Le Figaro, Umberto Boccioni está em Milão, após ter permanecido em Pádua até o final de 1907. Naquele tempo, a cidade, que seria exaltada pelos futuristas como o pólo da modernidade italiana, passava com maior evidência de cidade agrícola e artesanal a uma civilização industrial e capitalista, caracterizada por uma sociedade de massa, com todos os contrastes, as crises, as inquietudes e os entusiasmos que tal passagem implicava, com o surgimento e a expansão de fábricas, a organização do proletariado e as modificações urbanas.

Até então um pintor e desenhista que produziu alguns trabalhos esporádicos para a publicidade, Boccioni já havia criado várias telas, bem como participado de algumas exposições de arte. Os temas da sua pintura giravam entre aqueles idílicos - paisagens campestres, mulheres costurando ou lendo, interiores familiares -, temas marcadamente influenciados pela pintura de Giacomo Balla, de quem Boccioni fora aluno em Roma. Além da pintura, o artista desenvolvia paralelamente um abundante número de desenhos.

O Boccioni pré-futurista e recém-chegado a Milão encontra-se em crise: o ambiente da cidade é contraditório e de certa maneira obscuro para ele, que passa por momentos de muitas dúvidas. É um artista atormentado pela sua criação, amargurado pela solidão, confuso quanto aos rumos a seguir: pensa incessantemente e obsessivamente sobre qual tema colocar na sua pintura, qual 
1. PACINI, P.

Umberto Boccioni - pitture e sculture.

Florença: Nardini Editore, 1982, p. 17.

2. Diário de Boccioni, março de 1907. In: BIROLLI, Z. (Org.). Gli scritti editi e inediti. Milão: Feltrinelli, 1971, p. 236.

3. TOGNOLI, Carlo. Apud BORTOLOTTI,

N. (Org.). Boccioni a Milano. Milão: G. Mazzotta Editore, 1982, p. 1 .

4. Diário de Boccioni, 21/12/1907. In: BIROLLI (Org.). Op. cit., p. 271. estilo adotar em sua pincelada. Na procura por uma solução formal para suas indagações a respeito da arte, tornou-se um leitor ávido e interessado, um pesquisador agitado que alternava momentos de entusiasmo criativo com períodos de melancolia e desânimo. A tristeza pelo envelhecimento da mãe, o sentimento de culpa, a impotência diante dos acontecimentos e a precariedade das coisas são os medos de Boccioni, "tão antigos quanto o homem" .

Milão, em seu desenvolvimento industrial nascente, oferece ao artista a experiência do urbano, da metrópole, que ele já havia visto em Paris em 1906. As possibilidades passam a ser muitas; os rumos acerca da arte expandem-se e o confundem. $\mathrm{O}$ conflito no artista surge de sua necessidade de pintar uma arte nova, "fruto do nosso tempo industrial", aliada à sua resistência em abandonar os valores e temas de uma arte anterior, romântica e mística, voltada para questões mais existenciais do homem. O clima da cidade alvoroça os pensamentos do artista, que soube colher os aspectos mais estimulantes das transformações que ocorriam na cidade; sua arte "não foi otimista na exaltação da ciência e do progresso; ele retrata os contrastes e as angústias, resolvendo-as em estados d'alma

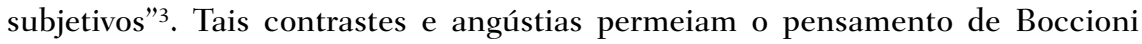
nesses seus primeiros anos milaneses, e a sua arte procurou ao menos organizar algumas questões.

Dessa forma, Milão apresentava para Boccioni o contrate entre o antigo e o moderno, que se tornaria apenas uma das dualidades da sua arte, um aspecto fortemente perceptível em seus desenhos do período. Em parte dialogando com a poética de artistas de cujas obras se aproxima por meio de exposições, livros e viagens, e ao mesmo tempo estabelecendo um diálogo íntimo com suas próprias dúvidas e inseguranças, Boccioni voltou-se para a criação de uma arte que contrasta temas como multidão e indivíduo, vida e morte, mundo celeste e mundo terrestre, antigo e moderno, carnal e espiritual. Em nenhum outro período de sua criação ele dedicou tamanha atenção a essas temáticas contrastantes, que iriam continuar de uma forma diversa em suas obras futuristas. Sua produção de desenhos no ano de 1908 carrega essa força antitética, concentrada de forma marcante na obra "Beata solitudo - Sola beatitudo".

Já no final de 1907 Boccioni manifestou a intenção de realizar uma ilustração gravada em cobre, como escreveu em seu diário em 21 de dezembro de 1907:

\footnotetext{
Veio-me a idéia de um desenho que transportarei para a gravura em cobre. O título: A Liberdade. A inspiração são as palavras de Ibsen: Possuir um caráter, ter a força de viver sem amigos, apenas com o próprio ideal: eis a liberdade exaltada... a isto se opõem as convenções humanas, o respeito aos parentes, a família... a verdadeira Liberdade acima de todas as misérias. A impossibilidade, a serenidade, a contemplação no alto em silêncio, no frio intenso talvez (beata solitudo - sola beatitudo) e abaixo as lutas, os trabalhos brutais, o amor, a guerra, a morte 4 .
} 
A gravura em cobre não foi realizada, mas a idéia do tema persistiu, levando o artista a criar duas versões para a obra: a primeira, provavelmente um estudo inicial, é realizada em 1907 em nanquim e lápis sobre papel; o segundo desenho, feito um ano depois em caneta sobre papel, tornou-se a versão final, mais carregada de detalhes e complexidade.

O desenho de 1908 apresenta na parte superior o sol brilhante, distribuindo do alto seus raios em direção à grande figura feminina, circundada por nuvens. Alheia a tudo e erguida acima de todos os dissabores e complexidades da vida terrestre, a figura está absorta em seus pensamentos. Duas pequenas placas, suspensas no céu, apresentam as frases "Beata solitudo" (à esquerda) e "Sola beatitudo" (à direita)5. O artista incluiu nos cantos superiores da obra o seu nome, o nome da cidade e o ano de execução do desenho, dados ausentes na primeira versão.

Mais abaixo da figura, ao lado direito, vemos um dirigível e, no lado esquerdo, um avião. A parte inferior do desenho inicia-se com a linha do horizonte, onde encontramos dois navios e seus reflexos nas águas, logo abaixo do avião. A paisagem terrestre é retratada em detalhes. Ao lado direito, um cenário urbano: casas, chaminés das fábricas expelindo fumaça, um trem que passa. Do lado esquerdo, uma paisagem mais árida, sem habitações, onde vemos uma longa estrada e vários postes com seus fios interligados. Essa faixa da ilustração é sustentada por uma arcada onde, de um lado, avança um trem e, de outro, uma fileira de cavalos marcha. No centro dessa faixa intermediária ergue-se uma arquitetura semelhante a um palácio.

A metade inferior do desenho apresenta a complexidade da vida terrestre: a luxúria, o pecado, o amor e o prazer, a oração, o trabalho, a guerra. Logo abaixo das arcadas, do lado direito, vemos uma massa de trabalhadores empunhando pás, picaretas e ancinhos, seguida, abaixo, por religiosos encapuzados, com as mãos cruzadas ao peito; ao lado esquerdo, surgem o exército e suas armas, e abaixo destes, padres com as mãos unidas em oração, com os olhares voltados ao céu. É nessa faixa do desenho que se destaca a figura do esqueleto empunhando uma foice, montado em um cavalo macabro, com os ossos aparentes. Abaixo das patas do animal Boccioni inseriu várias figuras humanas, sempre representadas duplamente: duas pessoas que se ameaçam com punhais; duas mulheres que, em pose de fervorosa prece, olham para o alto; outras duas figuras femininas, de longos cabelos e vestes negras, com as mãos estendidas ao céu. Todas essas figuras constroem uma espécie de moldura em cujo centro se encontra, envolta por uma aura luminosa, uma mulher com o seio nu alimentando um bebê. À esquerda dessa imagem, um velho está debruçado sobre um livro aberto, concentrado em sua atividade de leitura. Podemos ver vários livros empilhados perto dele, em cujas lombadas lêem-se palavras como Economia, Leis, Direito, Moral, Justiça, Religião, Guerra, Deveres. Em cima da pilha de livros, em primeiro plano, repousa uma coroa, ao lado de uma bomba prestes a explodir. No lado direito da
5. "Beata solitudo, Sola beatitudo": A frase "Beata solitudo sola beatitudo" é um dito latino. Traduzida livremente, significa "abençoada solidão, única bem-aventurança”, sendo utilizada no sentido de expressar o prazer ou o desejo de solidão e tranqüilidade. Atribui-se a autoria da frase a São Bernardo de Clairvaux (10901153), teólogo francês canonizado em 1174 pelo Papa Alexandre III. 
figura feminina com a criança, próximo de figuras humanas pequeninas, um casal demonstra afeto mútuo pelos olhares e pelas mãos que se tocam. Tal como o velho que lê, também o casal está alheio a tudo o que se passa a seu redor. Nas costas da figura masculina da dupla podemos ver um rosto humano, enigmático e sinistro, que parece olhar para o espectador. À esquerda do casal, um grupo espremido de cadáveres preenche um pequeno espaço.

Finalmente, em primeiro plano, ocupando uma parte do centro e da esquerda do desenho, uma mulher está reclinada sobre uma almofada, nua, vestindo sapatos, meias, um colar e um chapéu de grande aba, ornado por uma pluma. No seu braço direito enrosca-se uma serpente. Ela não apresenta qualquer sinal de pudor ao exibir seu corpo, confortavelmente deitada em tecidos estampados, enquanto olha para a figura masculina à sua esquerda, também nua e envolta em uma aura de sedução.

É fácil visualizar o grande contraste de idéias que existe em "Beata solitudo". Uma parte inferior mundana e complexa, carregada de toda sorte de paixões humanas, opõe-se a uma parte superior, tranqüila, meditativa, impregnada de uma confortante solidão. A compreensão desse desenho é facilitada se dedicarmos um pouco de atenção aos escritos do artista naquele ano. Esses textos são permeados por crises pessoais, inseguranças quanto ao futuro, a preocupação com a mãe doente e com a falta de recursos, a severa autocrítica em relação a suas pinturas, a dúvida entre a solidão e o convívio em sociedade; um contrastante intercalar de períodos de esperança e motivação com aqueles de desespero e desilusão, tanto a respeito de sua obra, quanto a respeito de sua vida e de seu papel no mundo.

No seu diário, Boccioni anotou cuidadosamente as leituras do período: os livros de teoria da pintura escritos por Previati, artista que conheceu pessoalmente em Milão (La tecnica della pittura, de 1905, e I principi scientifici del divisionismo, escrito em 1906), Baudelaire, Michelangelo, Segantini, Balzac, Schopenhauer, Ibsen (particularmente a obra Casa de bonecas), Nietzsche (em especial Assim falou Zaratustra, de 1884). A essas leituras, somam-se os componentes estilísticos que participam desse momento específico da vida do artista, registrados em seu diário: a obra de Munch, com sua espectralidade; o desenho secessionista e o linearismo decadente de Beardsley, estes dois últimos envolvidos no clima do Art nouveau; a presença da obra de Previati e Segantini e, por fim, a gráfica de Dürer e Rembrandt. Temos, dessa maneira, um caldo de influências, escritos e estilos que, somados, constituirão a essência de "Beata solitudo". Todos os principais elementos de sua poética concentram-se nesse desenho, que servirá de desdobramento para a maioria de suas obras futuras.

"Sinto cada vez mais a impossibilidade de viver em contato com o mundo",

6. Diário de Boccioni. In: BIROLLI (Org.). Op. cit., p. 272. escreve Boccioni em seu diário ${ }^{6}$. Essa frase abre uma longa discussão a respeito de um tipo de solidão humana, aquele que não é conseqüência de eventos terríveis, tampouco associado ao ostracismo, à punição, ou ao esquecimento; o artista está 
interessado na solidão escolhida por vontade espontânea, e não imposta pelos homens ou circunstâncias, necessária para a criação. A solidão como sinônimo de força é expressa pela figura feminina na parte superior de "Beata solitudo", concebida a partir de um desdobramento das leituras de obras de Friedrich Nietzsche, de Ibsen e da vida de Segantini. Particularmente, a obra do filósofo alemão Assim falou Zaratustra chamou a atenção de Boccioni pela abordagem da solidão humana, das vicissitudes da vida, da liberdade de pensar e da coragem de viver. Nietzsche pensa a obra como um apanhado de ensinamentos e sermões de um líder, Zaratustra, transmitidos em textos marcados por um aspecto sagrado, que constituem uma "religião" do homem na qual ele é ao mesmo tempo mestre e seguidor. Boccioni interessou-se por esse caráter místico do livro, aspecto que ele próprio via refletido na Natureza e na criação artística. No início de seu diário do ano de 1908, encontramos a prece que ele faz ao "Desconhecido" e à "Grande Mãe":

Que eu possa manter a humildade e a força de apresentar-me diante dos sagrados mistérios
como um inocente sem ambições e falsidade. Que tudo o que sair de minhas mãos seja um
canto de adoração e de exaltação da erva à árvore; de uma gota ao imenso céu, do verme ao
homem! Que tudo se transforme na minha mente segundo a Verdade suprema, sem julgar
nem bem nem mal, nem belo nem feio; que eu possa, sempre amando e estudando aquilo
que esteja de acordo com o meu sonho, não perder nunca a compreensão universal! ${ }^{\text {. }}$

Boccioni sempre entendeu a Arte como algo místico, ligado à inteligência superior, ao Grande Mistério, intangível aos homens. A partir desse modo de pensar ele questionará seu posicionamento no mundo, suas habilidades de artista, sua relação com o outro. A tentativa de encontrar soluções formais para sua arte também permite que ele desenvolva uma série de reflexões a respeito de si próprio, que oscilam entre uma empolgação para criar, uma motivação para os desafios da vida, e o pessimismo, a perda de esperança, as limitações e incapacidades de fazer com perfeição o que, segundo ele, tem de ser feito. Nesse sentido, sua simpatia - nem sempre abertamente admitida - por Michelangelo é um dos reflexos daquela angústia do gênio criador experimentada por Boccioni.

Essas oscilações de opinião que o artista alimenta a respeito de si, a sua forte autocrítica convivendo com o desejo de realizar algo grande, digno, são descritas claramente nos seus diários. $\mathrm{O}$ grande conflito que o aflige é como realizar esta Grande Arte, com que meios, e se ele é digno de tal tarefa. A dedicação a esses pensamentos imprime-se de certa forma nos desenhos, que possuem íntima relação com suas crenças e angústias. A necessidade de existência introspectiva fortalece-se: "certo, me vejo mudando e isto devo à minha solidão que faz com que eu me reencontre" .

A existência tímida do gênio criador que decide isolar-se do mundo nos leva imediatamente à obra de Giovanni Segantini (1858-1899), cuja influência no desenho de Boccioni está presente desde a época em que o artista vivia em Roma, nos primeiros anos do século XX. O ambiente cultural romano difundiu inúmeras reproduções da obra de Segantini, impressas em revistas, catálogos,
7. Diário de Boccioni, 02/01/1908. Idem, p. 273 .

8. Diário de Boccioni, 02/01/1908. Idem, p. 274 . 
9. ARGAN, G. C. Arte moderna. São Paulo: Cia. das Letras, 1993, p. 208.

10. Diário de Boccioni, 01/04/1908. In: BIROLLI (Org.). Op. cit., p. 300.

11. CALVESI, M.; COEN, E. Boccioni - l'opera completa. Milão: Electa, 1983 , p. 45.

artigos e monografias. A poética segantiniana teve uma participação na cultura da Sezession, com o seu conteúdo simbolista e alegórico, que condicionou o gosto de Boccioni nesses seus anos pré-futuristas.

A arte de Segantini está profundamente ligada à temática da solidão em "Beata solitudo" graças ao seu estilo introspectivo de vida. Argan, realizando um retrospecto do cenário artístico da Itália no início do século XX, comenta: "Na Itália há Previati, que assume ares de teórico, de combatente em todas as batalhas progressistas; sua contraparte é Segantini, com seus ares de asceta solitário, empenhado em ouvir as vozes da natureza $[. ..]{ }^{\prime 9}$.

De fato, a partir de 1891, Segantini abandonou a orientação naturalista a favor de interesses alegóricos e religiosos, sendo visto na Europa como um refinado artista místico, com a criação de grandes composições cósmico-naturais: a paisagem alpina torna-se motivo, para ele, de reflexão sobre o ciclo da vida e da morte. O idealismo da natureza, a identificação da presença do divino no corpo animado, aliados ao próprio estilo de vida do artista, isolado da multidão, atrairão Boccioni de forma marcante:

\footnotetext{
O sr. Chiattone me emprestou um livro sobre Segantini de Primo Levi! Não o terminei ainda, mas não sei o que escrever, tanto me comovem a obra, a vida, a alma deste grande! Acho muito justo - porque experimento isto em meu íntimo - o efeito que em Segantini produzia a solidão - Beata solitudo sola beatitudo! $[\ldots]^{10}$.
}

Essa relação mística com a natureza, que Boccioni retira tanto do Zaratustra de Nietzsche quanto da pintura de Segantini, após 1910 impedirá o artista, de acordo com Calvesi, “... de desenvolver a representação do movimento em um sentido mecanicista (como os outros futuristas)" ${ }^{11}$. Particularmente dois aspectos da poética de Segantini tornam-se centrais na sua arte: o sentimento religioso e solene em relação à natureza e o interesse pela temática da vida animal, que será presença constante nas suas obras inclusive futuristas; basta pensar na presença emblemática e constante do cavalo, porta-voz de um dinamismo natural, não-mecânico, ligado mais aos valores de uma filosofia romântica e idealizada do que a uma celebração da modernidade. Essa modernidade em Boccioni será sempre traduzida de uma forma mais íntima, desatrelada da sua imagem externa e celebrada por meio de uma visão universal de mundo.

Assim, a representação do movimento, da velocidade e do dinamismo, valores tão caros à vanguarda milanesa, seria resolvida na obra de Boccioni de uma forma intimamente ligada à experiência do sentimento cósmico, à necessidade de uma síntese "ideal". Não será à toa que Boccioni escolherá o homem e o cavalo como símbolos da energia dinâmica, diferentemente de Balla ou Russolo, que optarão pela glorificação do automóvel e da máquina.

A natureza mística de Segantini permeia "Beata solitudo" não somente 
por meio da temática da solidão, mas de maneira mais aparente: Boccioni, por exemplo, faz uma clara referência ao artista na figura do jovem casal situado no canto inferior direito do desenho, personagens principais da tela "O amor na fonte da vida" ("L'amore alla fonte della vita", 1896). Outra obra de Segantini pode ser citada neste momento: "Anjo da vida" ("Angelo della vita”) apresenta uma menina sentada no alto de uma árvore, isolada no céu.

A imagem da mulher sentada ao alto é apenas uma das alegorias presentes em "Beata solitudo", que reflete as escolhas simbolistas feitas pelo artista no período. Uma outra alegoria que merece atenção nesse desenho é a figura do esqueleto e seu cavalo, que domina boa parte do início da metade inferior da obra. O uso de alegorias da morte na produção artística não é nenhuma novidade nesse período, apresentando-se estreitamente ligado à pesquisa simbolista dos artistas do final do século XIX e início do XX, como ocorre com a obra de Boccioni. Esse esqueleto em seu cavalo reflete, além da atmosfera cultural do período, a importância da obra de Dürer na gráfica do artista, como lemos em seu diário:

Comprei três volumes sobre Dürer, Michelangelo, Rembrandt, magníficos [...].

Dürer é imenso, é grande, é um titã, é terrível quanto pode ser um gênio na sua criação.

Espantam-me por um lado a calma do estilo, e por outro o aspecto terrível da composição, o ímpeto do gesto que morde, contorce, deforma, mas corre, corre em direção do ideal! Como agarra tudo, bate, prega, talha, grita e depois se acalma, acaricia, alisa, aprimora, refina até que o sonho vá para bem longe; repousa para depois ressurgir e desafogar, e bater, e gritar! ${ }^{12}$.

A obra de Dürer manifesta-se em termos formais na gráfica de Boccioni, 12. Diário de BIROLLI (Org.). Op. cit., p. 278. fascinado pela sua linha descritiva e minuciosa, portadora de valores expressivos que vão muito além do contorno puro. A atração do artista italiano por esse tipo de linha é manifesta em outros desenhos do período, como "Perfil feminino" ("Profilo femminile"), de 1908, e "A mãe" ("La madre"), de 1909; a gravura de Dürer "Melancolia", realizada em 1514, também pode ser observada, em "Beata solitudo", na pose da figura feminina na parte superior.

Para a concepção dessa imagem da morte em "Beata solitudo", Boccioni faz uma referência às gravuras do artista alemão que compõem a série do “Apocalipse”, realizadas em 1498; Dürer executou, usando o método da xilogravura, quinze grandes lâminas que narram episódios do livro mais obscuro da Bíblia. Na lâmina de número 4, intitulada "Os quatro cavaleiros", os cavalos, furiosos, cavalgam ao encontro da multidão que, abaixo dos animais, manifesta terror e sofrimento. Um desses cavalos, magro e com as costelas aparentes, transporta um homem igualmente esquelético, embora poderoso.

A iconografia e o uso da linha de Dürer para a elaboração dessa imagem aliam-se à presença de outras obras e artistas ligados a esse tema alegórico. Aristide Sartorio (1860-1932) é um exemplo: na Bienal de Veneza de 1907, o artista ficou incumbido de realizar a decoração do salão central da mostra, incluindo os cavalos 
13. CALVESI. Op. cit., p. 38. da morte, aliados ao tema da vida que se renova, ilustrando, dessa forma, o contraste entre a castidade e a luxúria, e a luta constante entre elas. No seu diário de 1907 Boccioni citou esse trabalho, embora não tenha feito nenhum comentário a respeito.

Outro personagem importante para o entendimento da concepção dessa imagem é Gaetano Previati (1852-1920), artista fundamental na formação da poética de Boccioni. A pintura de Previati apresenta temas relacionados a episódios históricos, religiosos, obras literárias e alegorias mitológicas, onde a figura do cavalo é constante. Um exemplo é o tríptico "A heróica" ("L'eroica”), realizado em 1907, onde, no painel central, quatro cavalos empinam suas patas dianteiras, precipitando-se no espaço. Contudo, é de outra tela de Previati, intitulada "Os horrores da guerra" ("Gli orrori della guerra"), de 1894, que Boccioni retira a idéia do cavalo que galopa sobre os mortos. Em "Beata solitudo" a imagem desse animal e de seu cavaleiro macabro transmite uma ameaça que paira no ar, a sensação de iminência de uma tragédia, um memento mori.

A presença de uma atmosfera fúnebre e fatalista em "Beata solitudo" conduz-nos à obra gráfica do norueguês Edvard Munch. A referência à poética desse artista está presente em muitas pinturas e desenhos de Boccioni, influências que se estenderão até os seus primeiros trabalhos como futurista. No desenho em questão, um aspecto da iconografia de Munch merece atenção particular: a presença da figura humana que eleva seus braços para o alto. Esse elemento é o coração da estrutura da obra, conferindo-lhe uma sensação de verticalidade que marcará várias obras de Boccioni.

$\mathrm{O}$ artista certamente teve várias oportunidades de conhecer a obra do norueguês. Calvesi observa que "ao menos as suas gravuras foram conhecidas por Boccioni anteriormente, nem se pode excluir que ele já conhecesse Munch em seu período romano, enquanto artista-chave para a cultura das Secessões, e reproduzido nos escritos de Pica"13.

A divulgação da gráfica européia na Itália se deve, em parte, aos artigos escritos por Vittorio Pica para a revista Emporium, reunidos posteriormente nos fascículos Attraverso gli albi e le cartelle. Nos seus textos foram apresentados nomes como Goya, Daumier, Rops, Ensor, Munch e outros. A arte de Munch também esteve presente na "Nona Exposição Internacional de Arte da Cidade de Veneza”, em 1910, que Boccioni visitou; nela, Munch participou apenas com uma litografia: "Depois da queda".

Em termos gerais, a maioria da obra do artista nórdico aborda temas contrastantes: juventude e velhice, sagrado e profano, alegria e tristeza, saúde e doença, vida e morte. A transitoriedade implacável da vida, com suas desilusões e desesperos de toda sorte, a efemeridade dos encantos da juventude (principalmente os femininos), as paixões humanas que constroem e destroem desejos e ilusões compõem uma poética marcada pela morte, pela solidão e pela melancolia.

No que concerne a esta relação entre mundo inferior e mundo superior demonstrada principalmente com a elevação dos braços das figuras, podemos 
citar como exemplos marcantes da obra de Munch o estudo para "A montanha humana", de cerca de 1910, e a litografia "Marcha fúnebre", de 1897. Outra litografia que apresenta a imagem das mãos elevadas é "Concupiscência com a mulher (as mãos)", de 1895.

A litografia "Marcha fúnebre" é central para o entendimento de "Beata solitudo". Nessa gravura, uma reunião de corpos emerge do chão semeado de caveiras, formando uma pirâmide humana. Os braços e as mãos esticados e alongados ao máximo seguram um caixão aberto, invadindo o céu. Ao fundo, uma paisagem natural. A cena apresenta um contraste entre vida e morte, entre alto e baixo, numa oposição marcante de elementos: o caixão, objeto ligado à terra, agora se eleva ao céu; as pessoas, com seus corpos estendidos, parecem querer elevar-se com ele. Elas não parecem notar a presença de caveiras e cabeças humanas que cobrem o chão, deixadas para trás, um sinal do destino inevitável da matéria orgânica, a morte.

No caso do desenho de Boccioni, encontramos nas figuras de braços erguidos essa mesma idéia expressa em "Marcha fúnebre": o corpo humano volta-se para o céu, consciente de sua transitoriedade terrestre; as mãos estendidas para o alto parecem tocar a figura alegórica da morte, que, mais cedo ou mais tarde, ceifará todos os seres.

A imagem das mãos que se elevam ao alto comunica o contraste e a inevitável ligação entre o alto e o baixo, o superior e o inferior, o etéreo e o material, presentes em várias obras de Boccioni: os desenhos "Alegoria natalina" ("Allegoria natalizia"), "Multidão ao redor de monumento eqüestre" ("Folla intorno al monumento eqüestre"), seus dois ex-líbris (cujo motivo da espiral, de energia triunfante, reflete-se nas duas esculturas realizadas em 1912 com o tema da garrafa) ${ }^{14}$, "Figura alegórica ajoelhada" ("Figura allegorica inginocchiata") e as telas "Luto" ("Lutto"), "Briga na galeria" ("Rissa in galleria") e "A cidade que sobe" ("La città che sale"), todas de 1910. A forte presença do paradigma inferiorsuperior na obra de Boccioni, portanto, nasce a partir de duas influências principais: a poética de Munch e a leitura de Nietzsche, especialmente de Assim falou Zaratustra; esse livro está repleto de construções que aludem a imagens de aspecto vertical: o vôo da águia, a ascensão à montanha, por exemplo. Munch, ele mesmo um leitor ávido das obras de Nietzsche (o artista fará um retrato do filósofo alemão, nos anos de 1905-1906), atrairá Boccioni por meio do drama humano: "Agora que falo comigo mesmo e ninguém ri me interrompendo, eu digo isto: cristão ou pagão, humilde ou orgulhoso, fraco ou forte, eu não sei o que há em mim. Sei que vim ao mundo sorrindo e que partirei chorando!" 15.

A partir desse drama humano o artista procurou aliar a visão trágica da vida de Munch à idéia do filósofo, exposta nas palavras da personagem Zaratustra, de que, apesar da vida ser algo terrível, o ser humano possui a capacidade de tornar-se senhor de seu destino através da coragem, da auto-superação, da
14. As duas esculturas são "Formas-força de uma garrafa” (destruída) e "Desenvolvimento de uma garrafa no espaço", esta última integrante do acervo do MAC-USP.

15. Diário de Boccioni, 13/02/1908. In: BIROLLI (Org.). Op. cit., p. 279. 
16. Diário de Boccioni, 25/04/1908. In: BIROLLI. Op. cit., p. 304.

17. PACINI. Op. cit., p. 16-17. vontade de dizer um "sim" à existência, ultrapassando os valores estabelecidos, sem esquivar-se de nenhum aspecto da vida. Essas idéias de Nietzsche acerca da auto-superação do indivíduo estão fortemente presentes nas esculturas e estudos do dinamismo humano produzidos por Boccioni a partir de 1913.

Além de Munch, cuja poética tem presença marcante em "Beata solitudo", o desenhista e ilustrador Aubrey Beardsley (1872-1898) é outro artista que marcou a obra gráfica de Boccioni do período. Fascinado pela linha elegante, de traços etéreos, do inglês, o artista registra a descoberta de sua obra:

\begin{abstract}
Passei duas noites muito agitadas, plenas de sonhos. Não posso negar que isso se deve ao efeito de dois livros com ilustrações de Aubrey Beardsley que tenho nas mãos faz dois dias. [...] Suas ilustrações mostraram toda a minha inferioridade não somente na forma, mas na energia necessária, contínua, ininterrupta da cabeça que guia a mão. Confesso que sempre tenho a nítida sensação de que a minha mão não obedece a minha mente, que algo (quão original não sei) começo a ver no caos das idéias e das formas. Eu digo isso aos vinte e cinco anos e meio de idade e Beardsley morria, com vinte e seis, célebre desenhista, musicista, escritor, poeta!

Encontro nesse artista um potencial que Previati me aconselhava a atingir com estas palavras: Abandone-se, abandone-se, é necessário abandonar-se o máximo possível [... $]^{16}$.
\end{abstract}

A presença de Beardsley na gráfica de Boccioni está relacionada com o clima Art nouveau (ou Liberty, como era conhecido na Itália) respirado pela maioria dos países da Europa e difundido pelas Bienais de Veneza, cidade visitada pelo artista em 1907. O valor da linha é o principal foco de atenção de Boccioni, sendo perceptível em "Beata solitudo", por exemplo, no cuidado ao traçar as vestes da figura meditativa do plano superior e na figura feminina nua em primeiro plano; nesse caso, o inglês está presente tanto em termos formais quanto iconográficos: a mulher leviana, de enorme chapéu, parece ser retirada de alguma cena do decadentismo fin-de-siècle, tema pulsante no universo do desenhista inglês.

Torna-se necessário ressaltar a importância de Beardsley no emprego de uma linha presente em muitos desenhos de Boccioni no ano de 1908. "Beata solitudo" é uma das obras que reflete um gosto Art nowveau adquirido pelo artista não somente por meio da obra de Beardsley, mas de Obrist e de outros secessionistas, como Klimt, Van de Velde, Moser, Schmithals, Olbrich, Khnopff, e de arquitetos como Endell, do Ateliê Elvira em Munique, Horta, responsável pelo Hotel Solvay em Bruxelas, apenas para citar alguns. Nesse sentido, Beardsley, junto com Previati, constitui para Boccioni o contato com uma "pesquisa expressiva cada vez mais conscientemente antinaturalista e simbolista"17. Esse antinaturalismo e esse simbolismo auxiliam Boccioni na superação de uma arte de simples visão em favorecimento de uma arte de idéia, uma arte como manifestação visível do pensamento.

O conhecimento da linha modernista adquirido pela experiência Art nouveau estimula o artista a pensar sobre o caráter expressivo desta de uma forma mais consistente. Dentro de dois grandes eixos estéticos - o Simbolismo e o Art nouveau -, Boccioni aproxima-se da obra de vários artistas cuja pesquisa do mundo 
natural é caracterizada pelo domínio da linha e do desenho. Esses aspectos, que fazem parte da vivência pré-futurista de Boccioni, junto com o complexo ambiente cultural italiano no início do século XX, permitem ao artista expandir as possibilidades do uso da linha, tanto como elemento puramente formal, quanto como veículo expressivo. Essas reflexões desembocaram, mais tarde, na formulação do conceito de linha-força, um dos bastiões teóricos do Futurismo pictórico e escultórico.

É importante observar que
... a cultura e o ambiente artístico dos quais [Boccioni] se aproximará não condicionam mecanicamente a sua inventiva, a sua fantasia: agem como estímulos necessários, mas indiretos, tornando-lhe mais livre [...]. Na origem da sua arte está o homem, com seus contrastes psíquicos, os seus humores, as suas lutas, as inquietudes: é ele que se orienta em direção a certa cultura e não em direcão a outra, que sabe escolher, que sabe criticar. Os esquemas das tendências vêm depois ${ }^{18}$.

Em "Beata solitudo" podemos identificar vários elementos que estarão presentes em várias obras de Boccioni: a pose dos cavalos ao fundo alude à tela "A cidade que sobe"; as chaminés das fábricas constituirão cenário de fundo para muitas de suas pinturas; o trem nos recorda o tríptico "Estados d'alma"; a mulher que amamenta o filho serve de emblema para uma das temáticas mais constantes da obra de Boccioni: a mãe. Por fim, a figura feminina nua em primeiro plano no desenho é bastante semelhante à ponta-seca e ao pastel "Gisella", de 1907.

Na pintura, Boccioni encontrou no tríptico o suporte mais adequado para a expressão dessas idéias contrastantes, o meio ideal para estabelecer um diálogo entre o antigo e o moderno, a solidão e a multidão, os valores tradicionais do homem em oposição àqueles estimulados pela sociedade industrial nascente. $\mathrm{O}$ estudo para a tela "Veneremos a mãe" ("Veneriamo la madre"), de 1907-1908, é pensando sob a forma de tríptico, permanecendo dessa forma em seu resultado final. As duas versões para "Estados d'alma" ("Stati d'animo") 19 também são exemplos de trípticos conjugando elementos opostos: os indivíduos que partem em um trem e aqueles que permanecem na estação. A tela "A cidade que sobe" foi inicialmente pensada nesse tipo de suporte, com o título provisório de - outro indicador da atração do artista por uma temática de contrastes - "Giganti e pigmei" ("Gigantes e pigmeus").

O uso de um suporte tão tradicional, exaltado desde a arte medieval, confirma a relação particular e especial que Boccioni mantinha com a arte do passado, fortemente condensada em "Beata solitudo". Reconhecendo ali a importância de seus valores figurativos, o artista abriu caminho para a criação de uma arte nova, que não teme dialogar com a tradição. Mais do que criar "obras futuristas", Boccioni concentrou-se na criação de um "olhar futurista" para a história da arte européia. O que é algo muito moderno.
18. BALLO, G. Umberto Boccioni. Milão: Electa, 1960 , p. 48 .

19. Duas versões foram feitas para esse tríptico: uma anterior e outra posterior à segunda viagem do artista a Paris, em 1911. A primeira versão apresenta traços marcadamente expressionistas, enquanto a segunda incorporou alguns elementos do Cubismo francês. Ambas foram executadas naquele ano. 

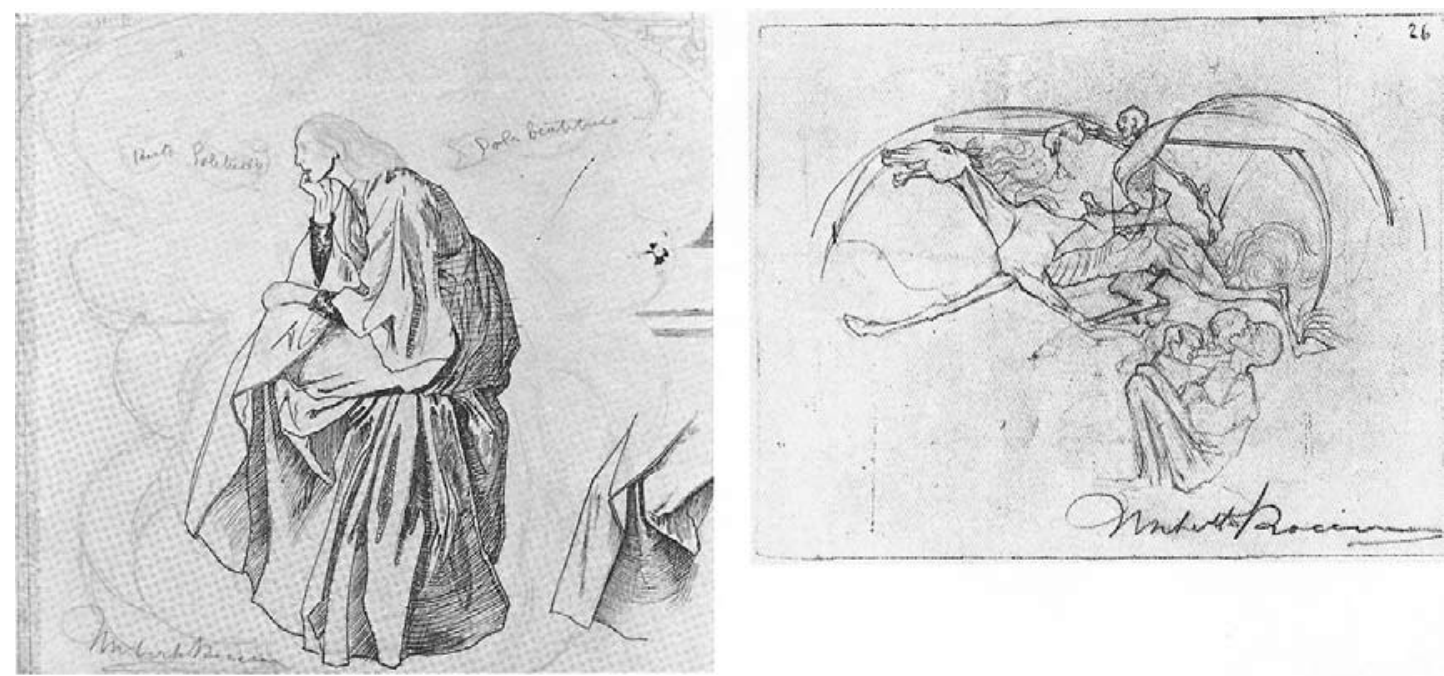

Vanessa Beatriz Bortulucce é graduada em História (UNICAMP, 1997), mestre em História da Arte e da Cultura (UNICAMP, 2000) e doutora em História Social (UNICAMP, 2005). Estuda o Futurismo italiano desde 1996, e atualmente é docente do Centro Universitário Assunção, em São Paulo. 

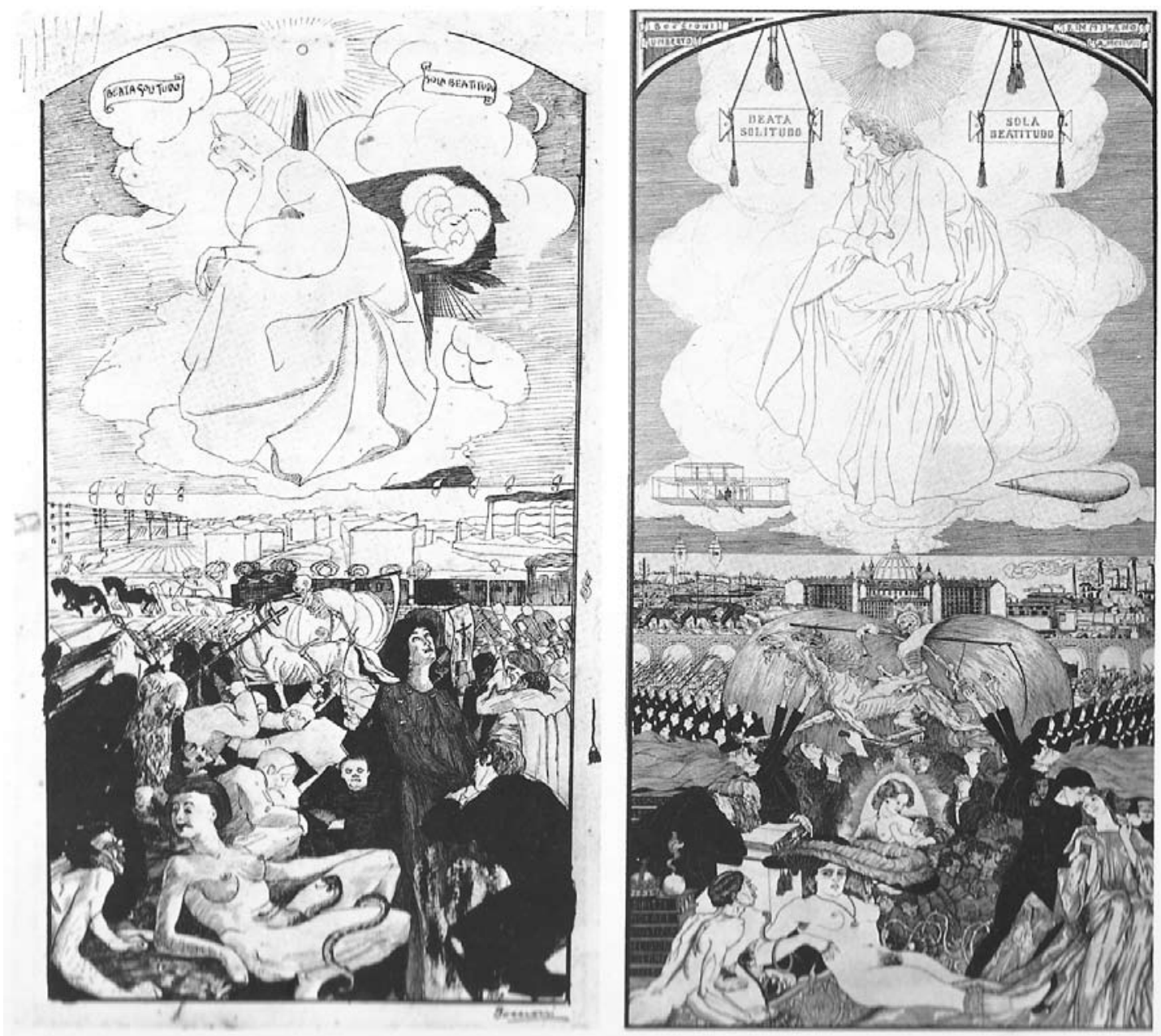